\title{
Türkiye Profesyonel Futbol Liglerindeki Takımların Stadyum Çim Türlerinin Araş̧tırılması
}

\author{
Barış TÜRKER ${ }^{1 *}$ \\ ${ }^{1}$ Trabzon Üniversitesi, Tonya Meslek Yüksekokulu, Trabzon, Türkiye
}

Orijinal Makale

Gönderi Tarihi: 03.03.2021

$\ddot{O} z$

$\mathrm{Bu}$ çalışmanın amacı Türkiye profesyonel futbol liglerindeki takımların stadyum çim türlerinin ve bu çim türlerinin ligler arasındaki dağılımının incelenmesidir. Çalışmada 2020-2021 sezonunda Türkiye profesyonel futbol liglerinde yer alan 145 takımın stadyumlarındaki çim tipleri araştırılmıştır. Stadyum çim tipi ile ilgili bilgilere Türkiye Futbol Federasyonu resmi sitesinden yararlanılarak ulaşılmıştır. Eksik bilgiler, kulüplerin web sitesinden ya da ilgili kulüplerle iletişime geçilerek tamamlanmıştır. Verilerin analizinde, SPSS 23 paket programı tercih edilmiş ve tanımlayıcı istatistiklerden faydalanılmıştır. Takımların oynadı̆̆ı çim yüzeyler değerlendirildiğinde; profesyonel liglerdeki takımların \%74'ü (n: 108) doğal çim, \%16's1 (n:23) sentetik çim ve \%10'u ise (n:14) hibrit çim sahalarda maçlarını oynadığı belirlenmiştir. Lig seviyesine göre çim tipleri incelendiğinde; süper ligdeki takımların, \%57'si (n:12) hibrit çim, \%43'ü (n:9) doğal çim, birinci ligdeki takımların ise; \%83'ü (n:15) doğal çim, \%11’i (n:2) hibrit çim ve \%6'sı (n:1) sentetik çim sahalarda maçlarını oynadığı belirlenmiştir. İkinci ve üçüncü liglerdeki takımların çim tipleri incelendiğinde ikinci ligdeki takımların; \%87'si (n:34) doğal çim, \%13’ü (n:5) sentetik çim, üçüncü ligdeki takımların ise \%75'i (n:50) doğal çim ve \%25'i (n:17) sentetik çim sahalarda maçlarını oynadığı tespit edilmiştir. Sonuç olarak profesyonel liglerde farklı oranlarda doğal, suni ve hibrit çim sahalar bulunmaktadır. Sporcu, antrenör ve sağlık ekibinin mücadele edeceği ligdeki zemin türlerini bilmesi hem sezon başı hem de maçlar oynanırken sporcuların sağlık ve performansına katkı sağlayacaktır.

Anahtar kelimeler: Sentetik çim, hibrit çim, doğal çim

\section{Investigation of The Stadium Turf Types of Teams In Turkey Professional Football Leagues}

\begin{abstract}
The aim of this study is to examine the stadium turf types of teams in Turkish professional football leagues and the distribution of these turf types between leagues. In the study, turf types in the stadiums of 145 teams participating in the Turkish professional football leagues in the 2020-2021 season were investigated. Information about the type of stadium turf was accessed by using the official site of the Turkish Football Federation. Missing information was completed on the website of the clubs or by contacting the relevant clubs. In the analysis of the data, the SPSS 23 package program was preferred and descriptive statistics were used. When turf surfaces played by teams were evaluated, it was determined that $74 \%$ (n: 108) of the teams in the professional leagues played their matches on natural grass, $16 \%(\mathrm{~N}: 23)$ on synthetic turf and $10 \%(\mathrm{~N}: 14)$ on hybrid turf pitches. When the types of turf are examined according to the league level; it was determined that $57 \%$ of the teams in the super League (n:12) on hybrid turf, $43 \%$ $(\mathrm{N}: 9)$ on natural grass, $83 \%$ of the teams in first league (n:15) on natural grass, $11 \%(\mathrm{n}: 2)$ on hybrid turf and 6\% (n:1) on synthetic turf play their matches. When the turf types of the teams in the second and third leagues are examined; it was found that $87 \%$ (n: 34 ) of the teams in the second league are on natural grass, $13 \%$ (n: 5) are on synthetic turf, and $75 \%$ (n: 50) of the teams in the third league are on natural grass, $13 \%$ (n: 5) are on synthetic turf play their matches. As a result, there are natural, synthetic and hybrid turf pitches in different proportions in professional leagues. Knowing the types of turf in the leagues of athletes, trainers and health crew will contribute to the health and performance of the athletes both at the beginning of the season and while the matchs are played.
\end{abstract}

Keywords: Synthetic turf, hybrid turf, natural grass.

\footnotetext{
* Sorumlu Yazar: Barış TÜRKER, E-posta: fzt.baristurker@gmail.com
} 


\section{GíRiş}

Futbol sahaları, futbol oyununun güzelliğini artıran, sporcular için oyun elverişliliğinin, izleyiciler için ise görsel kalitenin artmasında rol oynayan en önemli faktörlerdendir. Futboldaki teknik-taktik elementlerin optimum düzeyde uygulanmasında saha zemini büyük ölçüde belirleyici olmaktadır (Stiles, Guisasola, James ve Dixon, 2009). Futbol sahalarından beklenti, spor sırasında güvenliği ve yeterli sporcu performansını sağlamaktır (Fleming, 2011). Saha zemininin futboldaki belirli bileşenleri etkilediği bilinmektedir. Futboldaki mekanik ihtiyaçlar ve buna bağlı yaralanma riskleri, oyunun oynandığı yüzeyden dişsal bir risk faktörü olarak etkilenir (Strutzenberger, Cao, Koussev, Potthast ve Irwin, 2014). Ayrıca sporcunun başarısını etkileyebilecek olan şut isabet ve kinematiği, pas sayısı ve türü; kayarak müdahale sayısı ve yorgunluk algısının da zeminler arasında farklılık gösterdiği bilinmektedir (Andersson, Ekblom ve Krustrup, 2008).

Futbol geleneksel olarak doğal çim üzerinde oynanır ancak suni çimdeki gelişmelerle beraber, Uluslararası Futbol Birliği Kurulu (IFAB) 2004 yılında oyun kurallarına suni çim sahaları da eklemiştir (NédéLec, McCall, Carling, Le Gall, Berthoin ve Dupont, 2013). Son dönemlerde futbol sahalarında \%100 doğal çim, \%100 suni çim ve hem doğal hem de suni bileşenlere sahip olan hibrit çim olmak üzere üç temel yüzey malzemesi kullanılmaktadır (Ak ve Ögçe, 2018).

Doğal çim, maç ve antrenmanlarda en çok tercih edilen zemin türüdür (Jones, Page, Brogden, Langley ve Greig, 2020). Yapım maliyetinin düşük olması ve yüzde yüz doğal olması tercih edilmesindeki en önemli etkenlerdir. Ancak bu zeminin bazı dezavantajları bulunmaktadır. İklim koşullarına dayanıklılığının az olması, çok bakım istemesi, bakım maliyetlerinin yüksek olması ve çabuk deforme olması bunlardan bazılarıdır (Ekstrand, Timpka ve Hägglund, 2006).

Dünyanın birçok bölgesi, doğal çimin büyümesini sınırlayan iklim koşullarına sahiptir. Kuzey yarım küredeki soğuk ve nemli iklim bölgeleri ve ekvator çevresindeki kuru alanlarda doğal çim yetiştirmenin zorluğu, bu bölgelerde suni çim sahaların kullanımını artırmaktadır (Bjørneboe, Bahr ve Andersen, 2010). Daha uzun ve sık oyun oynama imkanı ve düşük bakım maliyetleri nedeniyle son yıllarda suni çim sahalar hem antrenman hem de müsabakalarda giderek daha fazla kullanılmaktadır (Rennie, Vanrenterghem, Littlewood ve Drust, 2016).

Hibrit çim sahalar sporcular için suni çimin yapaylık hissini yansıtmaması ve doğal çim zeminin bakım kaynaklı sorunlarını barındırmaması nedeniyle son dönemlerde futbol sahalarında sıklıkla tercih edilen bir zemin türüdür. Bu yöntemde doğal ve suni çim lifleri birlikte kullanılmaktadır. Hibrit çim zeminler şampiyonlar ligi, Avrupa ligi ve dünya kupası gibi büyük organizasyonların yapıldığı stadyumlarda kullanılan, kurulum aşaması maliyetli bir zemin türüdür (Ak ve Ögçe, 2018).

Dünyada ve ülkemizdeki futbol kulüplerinin mali durumu, sporcu sağllğı ve performansı, zeminin dayanıklılı̆̆ı, iklim şartları, zeminlerin kurulum ve bakım maliyetleri gibi faktörler takımların zemin tercihinde önemli rol oynamaktadır. Literatür incelendiğinde profesyonel futbol lig 
takımlarının stadyum çim tiplerinin araştırıldığı bir çalışmaya rastlanılmamıştır. Profesyonel liglerde sporcu, antrenör ve sağlık ekiplerinin stadyumlardaki çim tipi ve dağılımını bilmesi, farklı teknik-taktik ve koruyucu sağlık yaklaşımlarının geliştirilmesine katkı sağlayacaktır. Bu bilgiler ışığında bu çalışmanın amacı Türkiye profesyonel futbol liglerindeki takımların stadyum çim tiplerinin ve bu çim tiplerinin ligler arasındaki dağılımının incelenmesidir.

\section{YÖNTEM}

Tanımlayıcı tipteki araştırmada, 2020-2021 sezonunda Türkiye süper, birinci, ikinci ve üçüncü profesyonel liglerinde mücadele eden takımların stadyum çim tipleri değerlendirilmiştir. Değerlendirmeler yapılırken maçların oynandığı stadyum ve çim tipleri ilgili güncel verilerden yararlanılmıştır. Stadyum zeminleri ile ilgili bilgilere 10.01.2021-20.01.2021 tarihleri arasında Türkiye Futbol Federasyonu resmi web sitesinden (https://www.tff.org) yararlanılarak ulaşılmıştır. Eksik bilgiler, kulüplerin web sitesinden ya da ilgili kulüplerle iletişime geçilerek tamamlanmıştır.

\section{Verilerin değerlendirilmesi}

Verilerin değerlendirilmesinde, SPSS (Statistical Package for the Social Sciences) 23.0 paket programı kullanılmış ve tanımlayıcı istatistiklerden yararlanılmıştır. Çalışmada kategorik değişkenler için yüzde ve frekans değerleri kullanılmıştır.

\section{BULGULAR}

Araştırma kapsamında Türkiye süper, birinci, ikinci ve üçüncü futbol liglerinde mücadele eden toplam 145 profesyonel futbol takımının stadyum çim tipleri değerlendirilmiş̧ir. Grafik 1'de değerlendirilen takımların lig dağılımları gösterilmiştir.

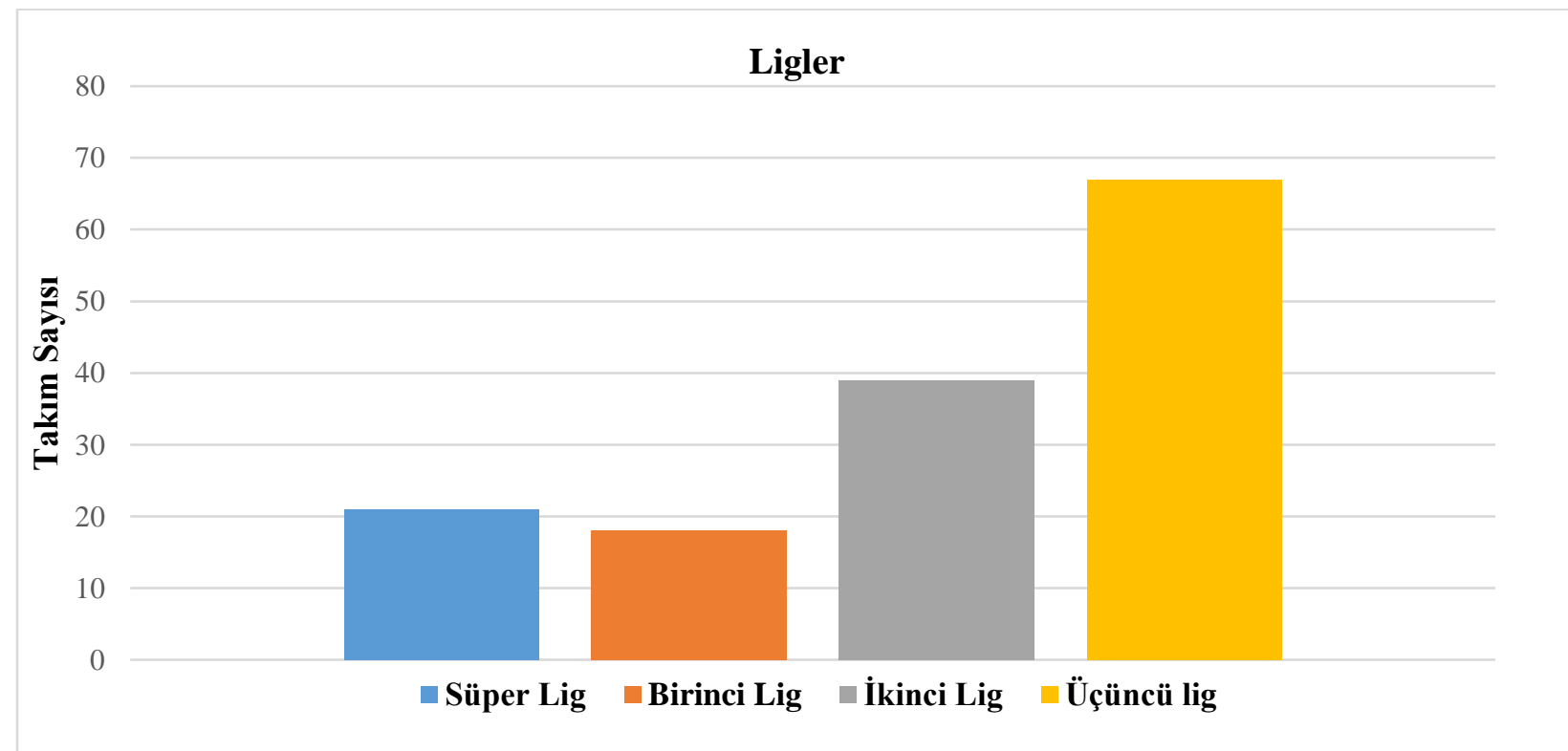

Grafik 1. 2020-2021 futbol sezonunda Türkiye profesyonel liglerinde mücadele eden takım sayıları 
Türker, B. (2021). Türkiye profesyonel futbol liglerindeki takımların stadyum çim türlerinin araştırılması. Avrasya Spor Bilimleri ve Eğitim Dergisi, 3(1), 51-60.

Tablo 1. Türkiye profesyonel futbol liglerindeki takımların stadyum çim tipi dağılımları

\begin{tabular}{lcc}
\hline Stadyum Çim Tipi Dağılımı & n & \% \\
\hline Doğal çim & 108 & 74 \\
Suni çim & 23 & 16 \\
Hibrit çim & 14 & 10 \\
\hline
\end{tabular}

n: Zemin Sayıs1, \%: Ligdeki oranı

Stadyumlardaki çim tipleri değerlendirildiğinde; takımların \%74'ü (n: 108) doğal çim, \%16's1 (n:23) sentetik çim ve \%10’u (n:14) hibrit çim sahalarda maçlarını oynadığı tespit edilmiştir (Tablo 1).

Tablo 2. Profesyonel futbol takımlarının lig seviyesine göre stadyum çim tiplerinin sayısı ve dağılımı

\begin{tabular}{lccc}
\hline & Doğal Çim (n, \%) & Suni Çim (n, \%) & Hibrit Çim (n, \%) \\
\hline Süper lig & $9(\% 43)$ & - & $12(\% 57)$ \\
Birinci lig & $15(\% 83)$ & $1(\% 6)$ & $2(\% 11)$ \\
İkinci lig & $34(\% 87)$ & $5(\% 13)$ & - \\
Üçüncü lig & $50(\% 75)$ & $17(\% 25)$ & - \\
\hline
\end{tabular}

n: Zemin Sayısı, \%: Ligdeki oranı

Lig seviyesine göre çim tipleri incelendiğinde; süper ligdeki takımların, \%57'si (n:12) hibrit çim, \%43'ü (n:9) doğal çim, birinci ligdeki takımların ise; \%83'ü (n:15) doğal çim, \%11'i (n:2) hibrit çim ve \%6'sı (n:1) sentetik çim sahalarda maçlarını oynadığı belirlenmiştir (Tablo 2). İkinci ve üçüncü liglerdeki takımların çim tipleri incelendiğinde ikinci ligdeki takımların; \%87'si (n:34) doğal çim, \%13'ü (n:5) sentetik çim, üçüncü ligdeki takımların ise \%75'i (n:50) doğal çim ve \%25'i (n:17) sentetik çim sahalarda maçlarını oynadığı tespit edilmiştir (Tablo 2).

\section{TARTIŞMA ve SONUÇ}

Profesyonel futbol liglerinde bulunan takımların stadyum çim tiplerinin ve bu çim tiplerinin ligler arasındaki dağılımının incelenmesini hedeflediğimiz çalışmamızda 2020-2021 sezonunda Türkiye profesyonel futbol liglerinde mücadele eden tüm takımların stadyum çim tipleri değerlendirilmiştir.

Araştırmamızın sonuçlarına göre Türkiye profesyonel futbol liglerinde saha zemini yapımında en çok doğal çim yöntemi kullanılmaktadır. Doğal çim zeminler uygun şartlar oluşturulduğunda spor için uygun bir zemindir ancak yetersiz bakım, yoğun kullanım ve kötü hava koşulları saha zemininin sürtünme ve sertlik gibi mekanik özelliklerini etkileyerek spor yaralanmaları için risk oluşturmaktadır ( Stiles vd., 2011; Williams, Hume ve Kara, 2011 ). Sporcularda sert zeminlerin kıkırdak yaralanmalarına yumuşak zeminlerin ise kas yorgunluğuna neden olduğu bilinmektedir (Orchard, 2001). Doğal çimin mekanik özelliklerinin değişmesi, spor yaralanmalarının dışında 
futbolcuların pas, şut ve müdahalelerini etkileyerek oyun kalitesini de düşürmektedir ( Andersson vd., 2008). Bu doğrultuda ülkemizde en çok tercih edilen zemin türü olan doğal çim üzerinde antrenman ve maçlarını oynayan takımların sporcu sağlı̆̆ı ve oyun kalitesini göz önünde bulundurarak zemin bakımlarına dikkat etmeleri gerekmektedir. Ayrıca Türkiye Futbol Federasyonu doğal çimin bozulma olasılığını düşünerek maç sıklığını ona göre ayarlamalıdır.

Araştırmamızın diğer bir sonucuna göre ülkemizdeki profesyonel futbol takımlarının stadyumlarında doğal çimden sonra en çok suni çim zeminlerin kullanıldığı belirlenmiş̧tir. Ayrıca lig seviyesi düştükçe suni çim oranının arttığı da görülmektedir. Suni çimin maliyet ve dayanıklılıkla ilgili bazı avantajları bulunmasına rağmen bu zemin tipinin bazı sakatlıkların oluşmasında risk faktörü olduğu bilinmektedir (Bjørneboe vd., 2010). Calloway vd., (2019) 20132016 yılları arasında 4 büyük ligde 2174 maç içi yaralanmayı kaydetmiş ve suni çimde oyun başına yaralanma oranını 1.54, doğal çimde ise bu oranı 1.49 olarak tespit etmiştir. Yine bu çalışmada yaralanma alt gruplarına bakıldığında, suni çim üzerinde ayak bileği yaralanması, aşil yaralanması ve ayak bileği kırığının istatistiksel olarak daha yüksek oranda görüldüğü belirlenmiştir (Calloway vd., 2019). Suni çimin yaralanmalara etkisinin yanında futbolcuların bu zemin türüne yönelik olumsuz algıları da bulunmaktadır. Roberts, Osei-Owusu, Harland, Owen ve Smith (2014) 1129 futbolcu ile yapmış oldukları çalışmada oyuncuların yüzde doksan birinin, suni çimde futbol oynamanın yaralanma riskini artırabileceğine inandığını belirtmiştir. Sporcuların yaralanma algısının yanında birçok futbolcu daha kötü top kontrolü, daha fazla fiziksel çaba ve daha az kayma hareketleri ile ilişkilendirerek yapay zeminde futbol oynamanın doğal zemine göre daha zor olduğunu belirtmiştir (Andersson vd., 2008). Bu nedenle suni çim sahalarda oynayan futbolcuların bu çim tipine yönelik algılarının değiştirilmesi ve yaralanmaların önlenmesine yönelik koruyucu yaklaşımların geliştirilmesi spora katılım ve performans açısından önem kazanmaktadır.

Ülkemizde hibrit çim sahalar sadece süper ligde bulunurken ikinci ve üçüncü liglerde bu zemine rastlanılmamıştır. Bu farkın oluşmasındaki en önemli neden hibrit çim zeminlerin kurulum maliyetlerinin yüksekliğindendir. Dünya futbolunun önde gelen takımları ve futboldaki büyük organizasyonların yapılmasında hibrit çim sahalar tercih edilmesine rağmen bu zemin türünün, sporcu sağlığı ve oyun kalitesi üzerine etkisinin araştırıldığı çalışmaya rastlanılmamıştır (Ak ve Ögçe, 2018). Hibrit çim zeminin bozulmasının zor ve yenilenme süresinin kısa olması gibi avantajları düşünüldüğünde bu zemin türünün profesyonel liglerde yaygınlaşması sporcu sağlığı ve oyun kalitesine olumlu katkıları olabilir.

Sonuç olarak profesyonel liglerde farklı oranlarda doğal, suni ve hibrit çim sahalar bulunmaktadır. Bu noktada antrenör ve sağlık ekiplerinin mücadele edeceği ligdeki zemin tipine göre sporcuları hazırlaması hem sezon başı hem de maçlar oynanırken sporcuların sağlık ve performansına katkı sağlayacaktır. 
Türker, B. (2021). Türkiye profesyonel futbol liglerindeki takımların stadyum çim türlerinin araştırılması. Avrasya Spor Bilimleri ve Ĕgitim Dergisi, 3(1), 51-60.

\section{ÖNERILER}

Araştırma sonucunda elde edilen bilgiler ışı̆̆ında öneriler aşağıda sunulmuştur;

- Türkiye liglerinde sentetik çim zeminlerin sayısının azaltılması,

- Son dönemlerde sıklıkla kullanılan hibrit çim zeminlerin sporcu sağlığı ve performans üzerine etkilerinin araştırıldı̆̆ı kanıt düzeyi yüksek bilimsel araştırmalar yapılması,

- Doğal çim zeminin bakımlarının uygun bir şekilde yapılması,

- Zemin çim tipinin ligdeki oranına göre antrenör ve sağlık ekibinin önlem almasının sağlanması

- Sporcuların zemin tipine algılarının belirlenmesi, önerilmektedir.

Çıkar Çatışması: Yazarlar arasında herhangi bir çıkar çatışması bulunmamaktadır.

Yayın Etiği: Mevcut çalışmanın yazım sürecinde "Yükseköğretim Kurumları Bilimsel Araştırma ve Yayın Etiği Yönergesi” kapsamında bilimsel, etik ve alıntı kurallarına uyulmuş olup; toplanan veriler üzerinde herhangi bir tahrifat yapılmamış ve bu çalışma herhangi başka bir akademik yayın ortamına değerlendirme için gönderilmemiştir. 
Türker, B. (2021). Türkiye profesyonel futbol liglerindeki takımların stadyum çim türlerinin araştırılması. Avrasya Spor Bilimleri ve Eğitim Dergisi, 3(1), 51-60.

\section{KAYNAKÇALAR}

Ak, M. K. ve Ögçe, H. (2018). Hibrit çim uygulama yönteminin futbol sahası örneğinde incelenmesi. Düzce Üniversitesi Bilim ve Teknoloji Dergisi, 6(4), 1000-1009. https://doi.org/10.29130/dubited.437350.

Andersson, H., Ekblom, B. \& Krustrup, P. (2008). Elite football on artificial turf versus natural grass: Movement patterns, technical standards, and player impressions. Journal of Sports Sciences, 26(2), 113-122. https://doi.org/10.1080/02640410701422076.

Bjørneboe, J., Bahr, R. \& Andersen, T. E. (2010). Risk of injury on third-generation artificial turf in Norwegian professional football. British Journal of Sports Medicine, 44(11), 794-798. https://doi.org/10.1136/bjsm.2010.073783.

Calloway, S. P., Hardin, D. M., Crawford, M. D., Hardin, J. M., Lemak, L. J., Giza, E., Forsythe, B., Lu, Y., Patel, B. H., Osbahr, D. C., Gerhardt, M. B., Mandelbaum, B. R. \& Baldwin, W. W. (2019). Injury surveillance in major league soccer: A 4-year comparison of injury on natural grass versus artificial turf field. American Journal of Sports Medicine, 47(10), 2279-2286. https://doi.org/10.1177/0363546519860522.

Ekstrand, J., Timpka, T. \& Hägglund, M. (2006). Risk of injury in elite football played on artificial turf versus natural grass: A prospective two-cohort study. British Journal of Sports Medicine, 40(12), 975980. https://doi.org/10.1136/bjsm.2006.027623.

Fleming, P. (2011). Artificial turf systems for sport surfaces: Current knowledge and research needs. Proceedings of the Institution of Mechanical Engineers, Part P: Journal of Sports Engineering and Technology, 225(2), 43-64. https://doi.org/10.1177/1754337111401688.

Hughes, M. G., Birdsey, L. Meyers, R., Newcombe, D., Oliver, J. L., Smith, P. M., Stembridge, M., Stone, K., \& Kerwin, D. G. (2013). Effects of playing surface on physiological responses and performance variables in a controlled football simulation. Journal of Sports Sciences, 31(8), 878-886. https://doi.org/10.1080/02640414.2012.757340.

Jones, A., Page, R., Brogden, C., Langley, B. \& Greig, M. (2020). The influence of playing surface on the loading response to soccer-specific activity. Journal of Sport Rehabilitation, 29(8), 1166-1170. https://doi.org/10.1123/JSR.2019-0327.

NédéLec, M., McCall, A., Carling, C., Le Gall, F., Berthoin, S. \& Dupont, G. (2013). Physical performance and subjective ratings after a soccer-specific exercise simulation: Comparison of natural grass versus artificial turf. Journal of Sports Sciences, 31(5), 529-536. https://doi.org/10.1080/02640414.2012.738923.

Orchard, J. (2001). The AFL penetrometer study: Work in progress. Journal of Science and Medicine in Sport, 4(2), 220-232. https://doi.org/10.1016/S1440-2440(01)80032-3.

Rennie, D. J., Vanrenterghem, J., Littlewood, M. \& Drust, B. (2016). Can the natural turf pitch be viewed as a risk factor for injury within sssociation football? Journal of Science and Medicine in Sport, 19, 547-552. https://doi.org/10.1016/j.jsams.2015.07.009.

Roberts, J., Osei-Owusu, P., Harland, A., Owen, A. \& Smith, A. (2014). Elite football players' perceptions of football turf and natural grass surface properties. Procedia Engineering, 72, 907-912. https://doi.org/10.1016/j.proeng.2014.06.150. 
Türker, B. (2021). Türkiye profesyonel futbol liglerindeki takımların stadyum çim türlerinin araştırılması. Avrasya Spor Bilimleri ve Ĕgitim Dergisi, 3(1), 51-60.

Stiles, V. H., Guisasola, I. N., James, I. T. \& Dixon, S. J. (2011). Biomechanical response to changes in natural turf during running and turning. Journal of Applied Biomechanics, 27(1), 54-63. https://doi.org/10.1123/jab.27.1.54.

Strutzenberger, G., Cao, H. M., Koussev, J., Potthast, W. \& Irwin, G. (2014). Effect of turf on the cutting movement of female football players. Journal of Sport and Health Science, 3(4), 314-319. https://doi.org/10.1016/j.jshs.2014.07.004. 


\section{EXTENDED ABSTRACT}

\section{Investigation of The Stadium Turf Types of Teams In Turkey Professional Football Leagues}

\section{Introduction}

Football is traditionally played on natural grass, however, with developments in artificial turf, the International Football Association Board added artificial turf pitches to the game rules in 2004. Recently, three basic surface materials have been used on football fields: $100 \%$ natural grass, $100 \%$ artificial turf and hybrid turf with both natural and artificial components. When the literature is examined, there is no study investigating the stadium grass types of professional football league teams. Knowing the type and distribution of turf in stadiums by athletes, trainers and medical teams in professional leagues will contribute to the development of different technical-tactical and preventive health approaches. In the light of this information, the aim of this study is to examine the stadium turf types of the teams in Turkish professional football leagues and the distribution of these turf types among the leagues.

\section{Method}

In the study, turf types in the stadiums of 145 teams participating in the Turkish professional football leagues in the 2020-2021 season were investigated. Information about the type of stadium turf was accessed by using the official site of the Turkish Football Federation. Missing information was completed on the website of the clubs or by contacting the relevant clubs. In the analysis of the data, the SPSS 23 package program was preferred and descriptive statistics were used.

\section{Findings}

When turf surfaces played by teams were evaluated, it was determined that $74 \%$ (n: 108$)$ of the teams in the professional leagues played their matches on natural grass, $16 \%(\mathrm{~N}: 23)$ on synthetic turf and $10 \%(\mathrm{~N}: 14)$ on hybrid turf pitches. When the types of turf are examined according to the league level; it was determined that $57 \%$ of the teams in the super League (n:12) on hybrid turf, $43 \%$ (N:9) on natural grass, $83 \%$ of the teams in first league (n:15) on natural grass, $11 \%(\mathrm{n}: 2)$ on hybrid turf and $6 \%$ (n:1) on synthetic turf play their matches. When the turf types of the teams in the second and third leagues are examined; it was found that $87 \%$ (n: 34 ) of the teams in the second league are on natural grass, $13 \%$ (n: 5) are on synthetic turf, and $75 \%$ (n: 50) of the teams in the third league are on natural grass, $13 \%$ (n: 5) are on synthetic turf play their matches.

\section{Discussion and Conclusion}

According to the results of our research, natural grass method is mostly used in the construction of the field floor in professional football leagues in Turkey. Insufficient maintenance, intensive use and bad weather conditions affect the mechanical properties of the natural field ground such 
as friction and hardness, creating a risk for sports injuries. It is known that hard floors cause cartilage injuries and soft floors cause muscle fatigue in athletes. The change in the mechanical properties of natural turf, apart from sports injuries, also reduces the quality of the game. In this direction, teams that play training and matches on natural grass, which is the most preferred ground type in our country, should pay attention to ground maintenance, taking into account the athlete's health and game quality. According to another result of our research, it was determined that artificial turf is the most used after natural turf in the stadiums of professional football teams in our country. Artificial turf has disadvantages being a risk factor for some injuries. In addition to the effect of artificial turf on injuries, football players also have negative perceptions of this type of ground. For this reason, changing the perceptions of football players playing on artificial turf for this type of turf and developing protective approaches to prevent injuries gain importance in terms of participation in sports and performance. Hybrid grass fields are only found in the Super League in our country, but this ground has not been found in the second and third leagues. The most important reason for this difference is the high construction costs of hybrid turf grounds. Considering the advantages of the hybrid grass, the widespread use of this type of ground in professional leagues may have positive contributions to the athlete's health and game quality. As a result, there are natural, artificial and hybrid turf pitches in different proportions in professional leagues. At this point, it will contribute to the health and performance of the athletes both at the beginning of the season and while the matches are played, if the trainers and medical teams prepare the athletes according to the type of ground in the league they will compete with.

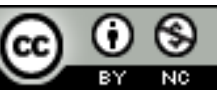

Bu eser Creative Commons Atıf-Gayri Ticari 4.0 Uluslararası Lisansı ile lisanslanmıştır. 